\title{
Abnormalities in soluble CD147 / MMPs / TIMPs axis in Ankylosing Spondylitis patients with and without a history of Acute Anterior Uveitis
}

\section{Anomalii ale axei CD147 solubil / MMPs / TIMPs la pacienții cu spondilită anchilozantă cu sau fără uveită acută anterioară}

\author{
Traian Costin Mitulescu ${ }^{1 *}$, Liliana Mary Voinea ${ }^{1,2}$, Denisa Predeteanu ${ }^{2,3}$, Leontina \\ Mirela Banica ${ }^{4}$, Crina Stavaru ${ }^{4}$, Cristiana Matache ${ }^{4}$ \\ 1. Department of Ophtalmology, University Emergency Hospital, Bucharest, Romania; 2. Carol Davila \\ University of Medicine and Pharmacy, Bucharest, Romania; 3. Department of Rheumatology, Sf. Maria \\ Clinical Hospital, Bucharest, Romania; 4. Cellular and Molecular Immunity Laboratory, Cantacuzino \\ National Institute for Research and Development in Microbiology and Immunology, Bucharest,
} Romania

\begin{abstract}
Ankylosing Spondylitis (AS) is the prototype of the axial form of spondyloarthritis. Despite extensive studies, complex mechanisms related to abnormal cellular and molecular processes in AS are not completely understood. Among proinflammatory mediators such as proinflammatory cytokines, NOS-2, chemokines, which lead to inflammation, matrix metalloproteinases (MMPs) play an important role in inflammatory processes that characterize $A S$. Therefore, we purposed to evaluate whether the disruption of extracellular MMPs inducer (EMMPRIN/CD147), MMPs and tissue inhibitors of MMPs (TIMPS) homeostasis play a role in the evolution of AS especially in patients with a history of Acute Anterior Uveitis (AAU). For this purpose sera from AS patients and from healthy donors (HDs) were assessed for soluble CD147 (sCD147), MMP-3 and TIMP-1 levels using enzyme-linked immunosorbent assay and for the activity of MMP-2 and -9 gelatinases by gelatin zymography. The experimental results showed that the levels of SCD147, MMP-3 and TIMP-1 were significantly increased in AS patients compared to HDs. $S C D 147$ as well as the ratio MMP-2/sCD147 differentiated AS patients with a history of AAU from those without it. The ratios MMP-2/sCD147, MMP-3/sCD147 and MMP-3/TIMP-1 suggested an imbalance between MMPS and their regulators in $A S$ patients. These results suggest that MMPs/sCD147 ratios could be potential biomarkers to strengthen the characterization of AS patients and to predict disease evolution. Positive or negative correlations between some of the experimental and/or clinical features of AS patients and the therapy also highlight the usefulness of the evaluation of these biomarkers to identify an individualized and efficient therapy.
\end{abstract}

Keywords: Ankylosing Spondylitis, Acute Anterior Uveitis, soluble CD147, MMPs, TIMPs

*Corresponding author: Traian Costin Mitulescu, University Emergency Hospital, Bucharest, Romania; e-mail: costin_mitulescu81@yahoo.com 


\section{Rezumat}

Spondilita Anchilozantă (SA) este prototipul formei axiale a spondiloartritelor. In pofida studiilor extinse, sunt încă incomplet ințtelese mecansimele complexe legate de procesele celulare și moleculare anormale din SA. Printre mediatorii inflamației, cum ar fi citokinele proinflamatoare, NOS-2, chemokinele, care conduc la inflamație, metaloproteinazele de matrice (MMPs) joacă un rol important în procesele inflamatoare care caracterizează SA. De aceea, ne-am propus să evaluăm dacă perturbări ale homeostaziei inductorului extracelular de MMPs (EMMPRIN/CD147), MMPs și inhibitorilor tisulari ai MMPs (TIMPs) joacă un rol în evoluția SA în special la pacienții care au în istoricul lor Uveită Acută Anterioară (UAA). In acest scop seruri de la pacienți cu SA și de la donatori sănătoși (DS) au fost analizate pentru nivelurile de CD147 solubil (sCD147), MMP-3 și TIMP-1 prin tehnica imunoenzimatica ELISA şi pentru activitatea gelatinazelor MMP-2 si MMP-9 folosind gelatin zimografia. Rezultatele experimentale au arătat că nivelurile de sCD147, MMP-3 si TIMP-1 sunt semnificativ crescute la pacienții cu SA comparativ cu DS. sCD147 ca și raportul MMP-2/sCD147 a diferențiat pacienții cu UAA de cei fără UAA în istoricul lor. La pacienții cu SA rapoartele MMP-2/sCD147, MMP-3/sCD147 și MMP-3/TIMP-1 au sugerat dezechilibrul dintre MMPs și reglatorii lor. Aceste rezultate sugerează că rapoartele MMPs/sCD147 pot deveni biomarkeri potențiali pentru întărirea caracterizării pacienților cu SA și pentru a prognoza evoluția bolii. Corelațiile pozitive și negative dintre anumite caracteristici experimentale și/sau clinice ale pacienților cu SA și terapie subliniază de asemenea utilitatea evaluării acestor biomarkeri pentru a identifica o terapie individualizată şi eficientă.

Cuvinte cheie: Spondilită Anchilozantă, Uveită Acută Anterioară, CD147 solubil, MMPs, TIMPs

Received: 12 ${ }^{\text {th }}$ June 2014; Accepted: $1^{\text {st }}$ November 2014; Published: $16^{\text {th }}$ November 2014.

\section{Introduction}

Ankylosing Spondylitis (AS) is a chronic inflammatory disease characterized by bilateral sacroiliac inflammation, variable inflammation of axial and peripheral joints, spinal ligament calcification, additional bone formation and spinal destruction leading to postural deformities as cervical and thoracic spine ankylosis (1). From an epidemiological point of view, the disease is prevalent in the second or the third decade of life, affects $0.5 \%$ of general population and has a male to female ratio of 2-3:1. It is worth mentioning that $90 \%$ of Caucasians with AS are positive for human leukocyte antigen HLA-B27, a class I major histocompatibility complex (MHC). However, no more than 5\% of HLA-B27 positive individuals develop AS (1). Therefore, it was hypothesized that other genetic factors, such as IL-23R, ERAP1, ANTXR2, CARD9, IL-1R, or innate immune Toll-like receptor-4 (TLR-4) may contribute to the disease development (2, $3)$. Over time, other biomarkers were evaluat- ed since inflammation is the major pivot of the disease. MMPs, cytokines, growth factors, bone alkaline phosphatase and collagen degradation products were analyzed (4). Thus, MMP-3 was found to be a valuable biomarker in patients with axial involvement, in strong and direct correlation with Bath Ankylosing Spondylitis Disease Activity Index (BASDAI) and Bath Ankylosing Spondylitis Functional Index (BASFI) (5). MMP-3 was also considered a good independent predictor of disease progression in AS patients with pre-existing radiographic changes (6).

Patients with severe and prolonged AS develop extra-articular manifestations such as: Acute Anterior Uveitis (AAU), bowel disease, skin, heart, lung, kidney and neurological involvement. Among these, AAU is the most common extra-articular manifestation of AS and may appear early in the course of the disease (7, 8). The prevalence of AAU in AS patients was found to be $21.5 \%$ - 30\% (7). Moreover, AS patients with iritis seem to have a more rapid 
functional limitation, based on BASFI (9). The pathological linkage between ocular disease and skeletal manifestations still remains unresolved. AAU is characterized by breakdown of the blood-aqueous barrier and acute inflammation of iris and ciliary body. Upregulation of adhesion molecules on the uveal vasculature and the local accumulation of pro-inflammatory cytokines (TNF- $\alpha$, and IFN- $\gamma$ ) and chemokines, that recruit and activate inflammatory cells into the uvea and anterior chamber, were considered the main factors of eye inflammation. The breakdown of the blood-aqueous barrier results in the leakage of serum protein from uveal vasculature in the anterior chamber and in fibrin formation (10). In patients with posterior uveitis, TNF- $\alpha$ affects MMPs and TIMPs expression, thus disrupting the extracellular matrix components and the blood-retinal barrier (11). It was suggested that these biomarkers are critical in tissue damage and repair processes and that in AAU their secretion is induced by pro-inflammatory cytokines such as TNF- $\alpha$ and IL- $1 \alpha$ which are known modulators of MMPs (12). The main sources of MMPs are infiltrated neutrophils and epithelial cells of the ciliary body. By continuous production of MMPs, neutrophils gain access to uveal tissue and aqueous humor amplifying inflammation (13). These enzymes increase the permeability of the blood-aqueous barrier in the uvea (14); therefore it was theorized that AAU etiology could be "auto-inflammatory" (15).

Based on previous data on MMPs roles in AS pathogenesis (4-6), we supposed that an impaired balance between extracellular matrix metalloproteinase inducer, EMMPRIN/CD147, MMPs and tissue inhibitors of MMPs (TIMPs) could play an important role both in triggering and maintaining inflammation in AS. Nowadays, there is no biomarker that might predict the evolution of AS patients with a history of AAU, a manifestation that can lead to serious complica- tions culminating with vision loss. Therefore, it is essential to identify a biomarker or a set of biomarkers which, in connection with the clinical investigations of ophthalmologists and rheumatologists, could predict the evolution of the disease.

CD147 is a transmembrane glycoprotein member of the immunoglobulin superfamily receptors, expressed by hematopoietic (e.g. activated $\mathrm{T}$ lymphocytes) and non-hematopoietic cells (e.g. corneal epithelial cells and retinal pigment epithelium) (16 - 18). In humans, CD147 was discovered by Biswas et al. (19) as a factor with the ability to stimulate fibroblasts to produce collagenase (MMPs). CD147 was shown to be involved in multiple biological processes. Mice deficient in CD147 are deficient in MCT1, 3 and 4 in the retinal pigment epithelium leading to blindness due to abnormal function of photoreceptors (20). Increased CD147 expression induced by EGF and TGF- $\beta$ was observed and it was suggested to contribute to wound healing. However, in chronic circumstances, when healing delays, a local sustained increase of CD147 and MMPs expression was associated with excessive matrix degradation and the cornea destruction (21). CD147-mediated intercellular interactions play multiple roles in some physiologic processes such as tissue remodeling by regulating the expression/secretion of MMPs and cytokines. On the other hand, CD147 was also involved in pathological processes (22).

Recently, it was discovered a soluble CD147 receptor released as a full length form by the breast cancer cells in culture promoting proMMP2 release from fibroblasts (23). A soluble full-length EMMPRIN resulted by microvesicle shedding by a mechanism dependent on protein kinase $\mathrm{C}$, calcium mobilization and mitogen-activated protein kinase (MEK 1/2) (24) and an active $22 \mathrm{kDa}$ fragment can be shed from tumor cells by the enzymatic action of MT1-MMP/ 
MMP-14 (25). The shorter molecular form of CD147 was also found in the tear fluid, aqueous humor, and vitreous samples suggesting that CD147 can regulate cell surface functions but also certain peri- and extracellular functions in the human eye (18). sCD147 was found in exudates after total knee arthroplasty (26), in sera of patients with systemic sclerosis (27), documenting its wide distribution in various body fluids and multiple biological and pathological functions. In patients with AS, a high expression of CD147 on immune cells was identified and CD147 expression level was associated with various inflammatory markers such as C-reactive protein (CRP) and erythrocyte sedimentation rate (ESR) (28).

Based on these considerations, we hypothesized the existence of an increased systemic release of $\mathrm{sCD} 147$ in patients with $\mathrm{AS}$, already characterized by exacerbated secretion of MMP3, MMP-2/9 (29 - 31) and high expression of CD147 on monocytes and lymphocytes (28). Therefore, we evaluated the equilibrium between some MMPs (MMP-2, MMP-9 and MMP-3) and their regulators ( $\mathrm{SCD} 147$, as inducer and TIMP-1, as natural inhibitor) in AS patients. Additionally, we focused on those subjects who had a history of AAU in order to identify potential biomarkers that might predict the evolution of the disease. We report alteration of some investigated biomarkers in pathological versus normal conditions pointing out their association with clinical features in AS patients.

\section{Materials and Methods}

\section{Patients and controls}

The study was conducted on forty patients and controls. A group consisting of thirty AS patients with a history of AAU (AAU AS patients) or without a history of AAU (wAAU AS patients) were recruited and characterized in Department of Rheumatology and Internal Medicine, $S f$. $M a-$ ria Clinical Hospital and Department of Ophthalmology, University Emergency Hospital, Bucharest, Romania. The selection of patients was based on New York criteria (32) modified in 1984 (33). Each patient was assessed for demographics (age, sex, and onset or disease duration) and clinical criteria [i.e. impaired skeletal type: axial and axial and peripheral type AS; presence of sacroiliitis by X-ray or magnetic resonance imaging (MRI); extra-articular manifestations: AAU, diarrhea, psoriasis; nonspecific inflammatory syndrome defined based on ESR, fibrinogen $(\mathrm{Fb})$ and CRP values; HLA-B27 serotype]. Also, for each patient the scores for disease activity BASDAI (34) and ASDAS (Ankylosing Spondylitis Disease Activity Score) (35) as well as for function BASFI (36) were calculated. During the period of investigation the patients received different types of therapies consisting of non biological [nonsteroidal anti-inflammatory drugs (NSAIDs), Sulphasalazine (SSZ)], and/or biological drugs [Infliximab (INF), Adalimumab (ADA), Etanercept (ETA), Golimumab (GOL)]. Tables 1 illustrate demographic, clinical and laboratory (A to C) features and the therapy (D) of studied AS patients. A suitable age and gender control group consisting of ten healthy volunteer donors (HDs) was formed. The study was approved by the Ethics Committee of the institutions involved according to the World Medical Association Declaration of Helsinki, revised in 2000, Edinburgh. Informed consent of all patients was obtained.

\section{Serum samples}

Peripheral blood obtained by venipuncture was collected from AS patients and HDs. After clotting, blood was centrifuged at $420 \mathrm{~g}$ and the obtained sera were stored at $-80^{\circ} \mathrm{C}$ until processing. 
Table 1. Demographic, clinical and laboratory features of AS patients

A.

\begin{tabular}{lccc}
\hline \multirow{2}{*}{ Characteristics } & $\begin{array}{c}\text { Grouping } \\
\text { criteria* }\end{array}$ & $\begin{array}{c}\text { Patients } \\
\text { (No.) }\end{array}$ & $\begin{array}{c}\text { Arbitrary } \\
\text { scores** }\end{array}$ \\
\hline Age & $>43.5$ & 15 & - \\
\cline { 2 - 4 } (years) & $<43.5$ & 15 & - \\
\hline \multirow{2}{*}{\begin{tabular}{l} 
Sex \\
\cline { 2 - 4 } $\begin{array}{l}\text { Duration of } \\
\text { disease }\end{array}$
\end{tabular}} & $\mathrm{F}$ & 2 & - \\
\cline { 2 - 4 } years) & $>9.5$ & 15 & - \\
\hline Axial & with & 9.5 & 2 \\
\hline \multirow{2}{*}{ Axial/Peripheral } & without & 21 & 1 \\
\cline { 2 - 4 } & with & 19 & 2 \\
\hline
\end{tabular}

*Values of grouping criteria are based on the median value calculated for each characteristic. **For Spearman's rank correlation, some of the clinical and laboratory biomarkers have received arbitrary scores.

C.

\begin{tabular}{|c|c|c|}
\hline Characteristics & $\begin{array}{c}\text { Grouping } \\
\text { criteria }\end{array}$ & Patients (No.) \\
\hline \multicolumn{3}{|c|}{ Inflammatory syndrome } \\
\hline \multirow{2}{*}{$\operatorname{ESR}(\mathrm{mm} / \mathrm{h})$} & $>30$ & 8 \\
\hline & $<30$ & 22 \\
\hline \multirow{2}{*}{$\mathrm{Fb}(\mathrm{mg} / \mathrm{dl})$} & $>400$ & 9 \\
\hline & $<400$ & 21 \\
\hline \multirow{2}{*}{ CRP (mg/l) } & $>2$ & 27 \\
\hline & $<2$ & 3 \\
\hline \multicolumn{3}{|l|}{ Gene phenotype } \\
\hline \multirow{2}{*}{ HLA-B27 } & positive & 28 \\
\hline & negative & 2 \\
\hline \multicolumn{3}{|l|}{ Index } \\
\hline \multirow{3}{*}{ BASDAI } & $>5$ & 7 \\
\hline & $4-5$ & 3 \\
\hline & $<4$ & 20 \\
\hline \multirow{4}{*}{ ASDAS } & $>3.5$ & 6 \\
\hline & $2.1-3.5$ & 9 \\
\hline & $1.3-2.1$ & 9 \\
\hline & $<1.3$ & 6 \\
\hline \multirow{3}{*}{ BASFI } & $>6.5$ & 5 \\
\hline & $4.5-6.5$ & 3 \\
\hline & $<4.5$ & 22 \\
\hline
\end{tabular}

B.

\begin{tabular}{lccc}
\hline Characteristics & $\begin{array}{c}\text { Grouping } \\
\text { criteria }\end{array}$ & $\begin{array}{c}\text { Patients } \\
\text { (No.) }\end{array}$ & $\begin{array}{c}\text { Arbitrary } \\
\text { scores }\end{array}$ \\
\hline Articular manifestations & & \\
\hline \multirow{4}{*}{ Sacroiliitis } & $\begin{array}{c}\text { with/without } \\
\text { (by X ray) }\end{array}$ & $28 / 2$ & - \\
\cline { 2 - 4 } & $\begin{array}{c}\text { with/without } \\
\text { (by MRI) }\end{array}$ & $2 / 28$ & - \\
\hline \multirow{2}{*}{ Extra-articular manifestations } & & \\
\hline \multirow{2}{*}{ AAU } & with & 14 & 2 \\
\cline { 2 - 4 } & without & 16 & 1 \\
\cline { 2 - 4 } Diarrhea & with & 1 & - \\
\hline \multirow{2}{*}{ Psoriasis } & without & 29 & - \\
\cline { 2 - 4 } & with & 0 & - \\
\hline
\end{tabular}

D.

\begin{tabular}{lccc}
\hline \multirow{2}{*}{ Therapy } & $\begin{array}{c}\text { Grouping } \\
\text { criteria }\end{array}$ & $\begin{array}{c}\text { Patients } \\
\text { (No.) }\end{array}$ & $\begin{array}{c}\text { Arbitrary } \\
\text { scores* }\end{array}$ \\
\hline non biologic & & 14 & 2 \\
\hline \multirow{2}{*}{ NSAIDs } & yes & 16 & 1 \\
\cline { 2 - 4 } & no & 11 & 2 \\
\hline \multirow{2}{*}{ SSZ } & yes & 19 & 1 \\
\hline \multirow{2}{*}{ biologic } & no & & 2 \\
\hline \multirow{2}{*}{ INF } & yes & 14 & 1 \\
\cline { 2 - 4 } & no & 16 & 2 \\
\cline { 2 - 4 } ADA & yes & 5 & 1 \\
\hline \multirow{2}{*}{ GOL } & no & 25 & 2 \\
\cline { 2 - 4 } & yes & 1 & 1 \\
\hline \multirow{2}{*}{ ETA } & no & 29 & 2 \\
\cline { 2 - 4 } & yes & 3 & 1 \\
\hline
\end{tabular}

*For Spearman's analysis, depending on the presence or absence of each type of therapy, patients received arbitrary scores: 1 (without a therapy type) and 2 (with a therapy type). 


\section{Assessment of SCD147, MMP-3 and \\ TIMP-1 biomarkers by ELISA}

The evaluation of SCD147, MMP-3 and TIMP-1 levels in human sera (AS patients and HDs) was performed using ELISA commercial kits [Quantikine Human EMMPRIN Immunoassay, Quantikine Human Total MMP-3 Immunoassay and Quantikine Human TIMP-1 Immunoassay (R\&D Systems, Minneapolis, USA)] according to manufacturer's instructions.

\section{Assessment of MMP-2 and MMP-9 activity}

by gelatin zymography

Semi-quantitative evaluation of MMP-2 and MMP-9 activity was done using the previously described method of gelatin zymography (37). Briefly, serum proteins were resolved by $8 \%$ SDS-PAGE gel containing 1\% gelatin. After electrophoresis, gels were incubated in a substrate solution and stained with Coomassie Brilliant Blue R. After staining, the zymograms were scanned and densitometry analysis was performed using TotalLab v1.11 software. MMPs enzyme activity was expressed as Arbitrary Units (AU) divided by $10^{4}$.

\section{Statistical analyses}

The significance of the differences between AS patients and HDs or between different subgroups of AS patients was based on the probability $(p)$ value calculated by Mann-Whitney $\mathrm{U}$ test. A $p$ value $<0.050$ was considered as significant. Spearman's coefficients (r) were also calculated to evaluate the association between clinical, laboratory and experimental biomarkers. A correlation coefficient $|\mathrm{r}|>0.5$ with a $p<0.050$ was considered significant.

\section{Results}

The activity of MMP-2 and MMP-9 in sera of AS patients and HDs

A typical image of substrate zymography performed on sera from AAU AS and wAAU AS patients and HDs is presented in Figure 1. Both the active (a) and latent (1) forms of gelatinases were identified for MMP-9 while for MMP-2 only the latent form (1MMP-2) was present. As the two forms of the MMP-9 gelatinase were not clearly delimited the activity of total MMP-9 (tMMP-9) was evaluated by densitometry. The results of zymograms analysis for all AS patients and HDs are presented in Table 2. Both gelatinases have a higher activity in AS patient sera compared to HDs sera, but the differences are not statistically significant. Furthermore, there is no statistically significant difference between AAU AS and wAAU AS patients regarding MMP-2 and MMP-9 activities.

\section{The level of MMP-3 in sera of AS patients and HDs}

We assessed the level of MMP-3 in sera of AS patients and HDs and the results are presented in Figure $2 a$. Indeed, ELISA results show that the serum MMP-3 level is significantly increased in AS patients compared to HDs $(p=0.002)$,

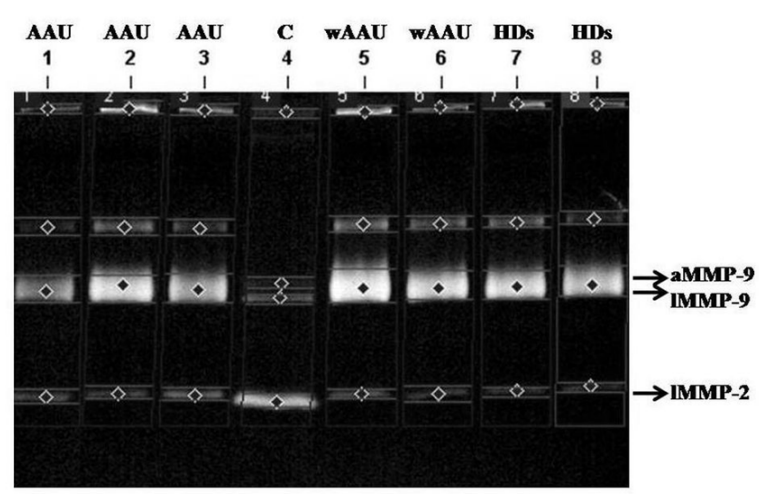

Figure 1. MMP-2 and MMP-9 activity in AS and HDs sera. Sera from three AAU AS patients (lines 1-3), two wAAU AS patients (lines 5 and 6), two HDs (lines 7 and 8 ) and fetal calf serum (C, line 4, as source of latent and active forms of MMP-2 and MMP-9) were analyzed by gelatin zymography as described in Material and Methods caption. The positions of active (a) and latent (1) forms of enzymes are indicated in the figure by arrows. 
Table 2. IMMP-2 and tMMP-9 activity in AS patients and HDs. Sera from AS patients and HDs were analyzed for 1MMP-2 and tMMP-9 activity by gelatin zymography. The results of zymograms densitometry are presented as median and range for each gelatinase and each investigated group of AS patients (AS, AAU AS", wAAU AS and HDs).

\begin{tabular}{lcc}
\hline Group & tMMP-9 activity $\left(\mathbf{A U} / \mathbf{1 0}^{4}\right)$ & IMMP-2 activity (AU/10 $)$ \\
\hline AS & $760.62(139.77-1876.09)$ & $78.83(32.66-171.40)$ \\
\hline AAU AS & $710.56(139.77-1737.32)$ & $85.44(32.66-155.35)$ \\
\hline wAAU AS & $787.04(292.02-1876.09)$ & $75.98(38.73-171.4)$ \\
\hline HDs & $478.65(90.83-1127.70)$ & $69.33(39.71-104.70)$ \\
\hline
\end{tabular}
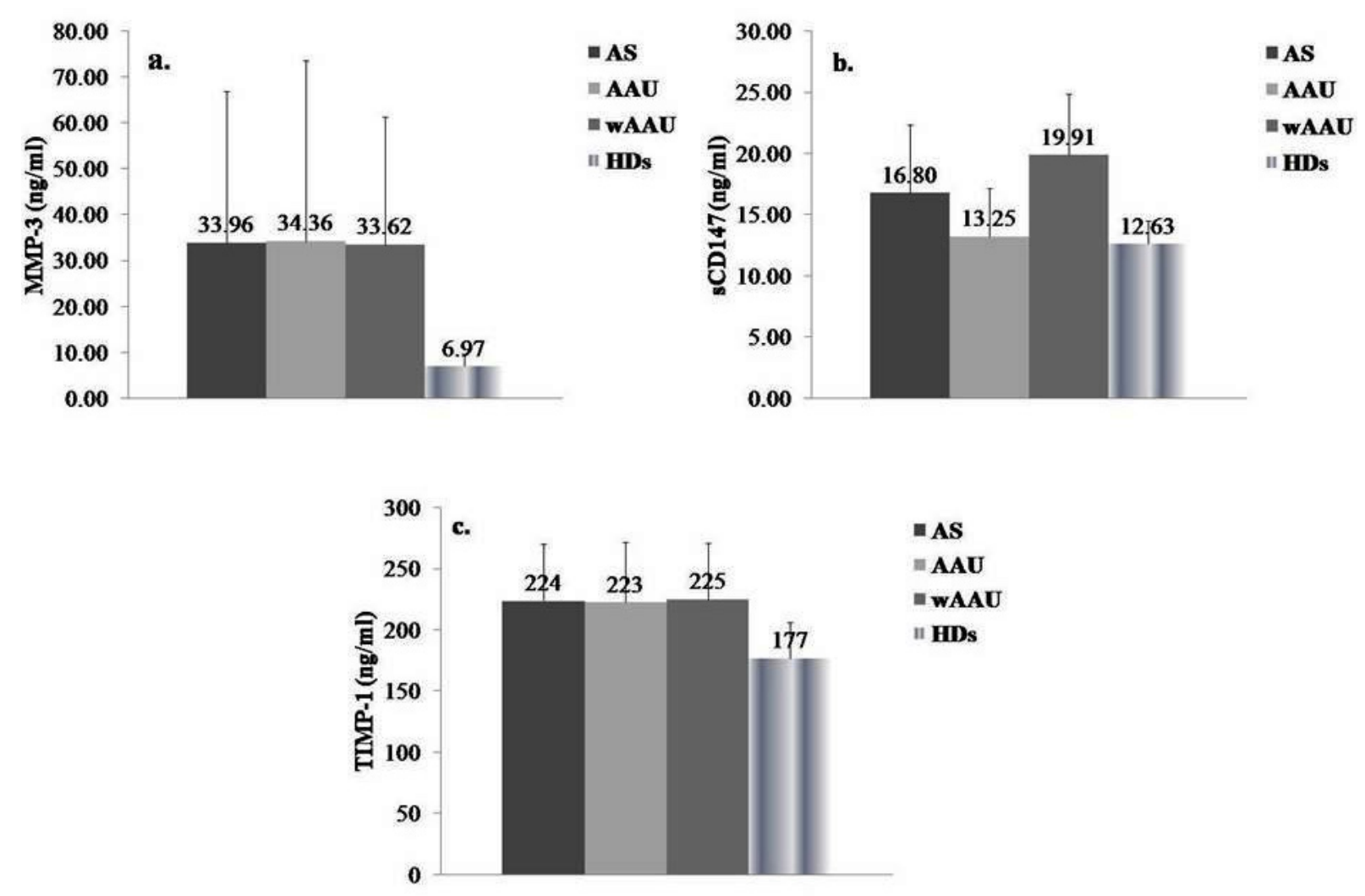

Figure 2. The level of MMP-3, sCD147 and TIMP-1 in AS and HDs sera. Sera from fourteen AAU AS and sixteen wAAU AS patients and ten HDs were analyzed by ELISA for the level of MMP-3 (a), sCD147 (b) and TIMP-1 (c). The figure includes mean values and the error bars for standard deviations (SD) calculated for each investigated group. 
regardless of AAU history ( $p=0.019$ for AAU AS patients $v s$. HDs and $p=0.001$ for wAAU AS patients $v s$. HDs). It is important to mention that MMP-3 level does not differentiate between AAU and wAAU AS patients.

\section{The level of SCD147 in sera of AS patients and HDs}

The level of sCD147 was also evaluated in order to emphasize whether a possible disorder at this level may be associated with AAU history in AS patients. As displayed in Figure $2 b$, AS patients have significantly higher serum SCD147 levels than HDs $(p=0.036)$. However, considering AAU history, only wAAU AS patients have significantly higher level of SCD147 than HDs $(p=0.0002)$ while AAU AS patients have comparable serum sCD147 level with HDs ( $p=$
0.940). Furthermore, the level of sCD147 is significantly lower in sera of AAU AS patients than in sera of wAAU AS patients $(p=0.001)$.

\section{The level of TIMP-1 in sera of AS patients and HDs}

TIMP-1 is one of the most important inhibitors of MMP-3 and MMP-9; therefore we evaluated its level in AS patient and HDs sera. The results of ELISA are presented in Figure $2 c$. Serum level of TIMP-1 for all investigated AS patients is significantly higher compared with HDs ( $p=0.017$ for AS patients $v s$. HDs, $p=0.040$ for AAU AS patients $v s$. HDs and, $p=0.025$ for wAAU AS patients vs. HDs) and does not differentiate between AAU AS and wAAU AS patients $(p>0.05)$.

Table 3. The balance between MMP-2, -3 or -9 and SCD147 in AS patients and HDs. The ratios between MMP$2,-3$ or -9 and $\mathrm{sCD} 147$ were calculated for each individual. Median and range of the ratios for each investigated group (A) and statistically significant differences between AS patients and HDs or between the groups of AS patients are presented (B).

A.

\begin{tabular}{lccc}
\hline Group & $\begin{array}{c}\text { tMMP-9/ } \\
\text { SCD147 }\end{array}$ & $\begin{array}{c}\text { IMMP-2/ } \\
\text { SCD147 }\end{array}$ & $\begin{array}{c}\text { MMP-3/ } \\
\text { SCD147 }\end{array}$ \\
\hline AS & $49.87(8.98-203.33)$ & $5.15(1.62-11)$ & $1.18(0.15-10.95)$ \\
\hline AAU AS & $51.84(15.48-203.33)$ & $7.1(2.8-11)$ & $1.16(0.15-10.95)$ \\
\hline wAAU AS & $46.74(8.98-88.32)$ & $4.11(1.62-7.58)$ & $1.3(0.29-5.12)$ \\
\hline HDs & $37.63(6.56-78.86)$ & $5.16(2.87-7.74)$ & $0.62(0.22-0.74)$ \\
\hline
\end{tabular}

B.

\begin{tabular}{lcccc}
\hline Group & $\begin{array}{c}\text { Mann-Whitney } \\
\text { U test }\end{array}$ & $\begin{array}{c}\text { IMMP-2/ } \\
\text { sCD147 }\end{array}$ & $\begin{array}{c}\text { tMMP-9/ } \\
\text { sCD147 }\end{array}$ & $\begin{array}{c}\text { MMP-3/ } \\
\text { SCD147 }\end{array}$ \\
\hline AS vs. HDs & $p$ & 0.574 & 0.684 & $\mathbf{0 . 0 0 7}$ \\
\hline AAU AS vs. HDs & $p$ & 0.277 & 0.526 & $\mathbf{0 . 0 0 8}$ \\
\hline wAAU AS vs. HDs & $p$ & $\mathbf{0 . 0 4 9}$ & 0.920 & $\mathbf{0 . 0 2 5}$ \\
\hline AAU AS vs. wAAU AS & $p$ & $\mathbf{0 . 0 0 7}$ & 0.547 & 0.786 \\
\hline
\end{tabular}




\section{The relationship between MMPs and sCD147 in AS patients and HDs}

An important number of papers discussing the physiological and pathological roles of CD147 and MMPs interplay were published. Based on these, we analyzed the balance between IMMP2, MMP-3 or tMMP-9 and SCD147 taking into consideration the results generated by the values of 1MMP-2/sCD147, MMP-3/sCD147 and tMMP-9/sCD147 ratios (Table 3A). The highest values of these three ratios are identified in AAU AS patients. Among these ratios, only 1MMP-2/ sCD147 ratio significantly differentiates AAU AS from wAAU AS patients (Table 3B). MMP3/sCD147 ratio appears as an important parameter to distinguish AS patients with or without AAU from HDs, while tMMP-9/sCD147 ratio does not differentiate between the compared groups of subjects.

\section{The relationship between MMPs and TIMP-1 in AS patients and HDs}

We compared AS patients with HDs regarding the ratios MMP-3/TIMP-1 and tMMP-9/ TIMP-1 in order to evaluate the equilibrium between these two MMPs and their specific inhibitor. The results of this analysis are presented in Table 4. MMP-3/TIMP-1 ratio is statistically significantly higher in AS patients group ( $p=$ $0.002)$ or in AAU AS $(p=0.008)$ and wAAU AS

Table 4. The balance between MMP-3 or MMP9 and TIMP-1 in AS patients and HDs. The ratios between MMP-9 or MMP-3 and TIMP-1 were calculated for each investigated individual. Median and range of the ratios for each investigated group are presented.

\begin{tabular}{lcc}
\hline Group & $\begin{array}{c}\text { tMMP-9/ } \\
\text { TIMP-1 }\end{array}$ & $\begin{array}{c}\text { MMP-3/ } \\
\text { TIMP-1 }\end{array}$ \\
\hline AS & $2.97(0.69-8.69)$ & $0.1(0.01-0.43)$ \\
\hline AAU AS & $2.61(0.69-8.69)$ & $0.09(0.01-0.43)$ \\
\hline wAAU AS & $3.25(1.56-8.56)$ & $0.12(0.03-0.37)$ \\
\hline HDs & $2.93(0.48-5.31)$ & $0.04(0.02-0.06)$ \\
\hline
\end{tabular}

( $p=0.002$ ) patient groups than in HDs group, while tMMP-9/TIMP-1 ratio is comparable between the groups.

\section{Clinical variables that make the difference} between $A A U A S$ and $w A A U A S$ patients

Our results showed that in AS population the occurrence of axial and peripheral type of disease directly correlates with BASDAI $(\mathrm{r}=0.454$, $p=0.012)$ and BASFI $(\mathrm{r}=0.488, p=0.006)$. In concordance with these observations, the same variables differentiate between AAU AS and wAAU AS patients. As displayed in Table 5 BASDAI and BASFI are significantly higher in AAU AS compared to wAAU AS patients.

\section{Correlations between experimental bio- markers and clinical variables of $A S$ pa- tients}

To evaluate whether any of the analyzed biomarkers are related to the existence of AAU in the history of AS patients, the experimental biomarkers were correlated, using Spearman's rank correlation test, with the variables currently used for AS patients characterization [axial or axial and peripheral type, the presence or absence of AAU in AS patients history, inflammation markers (ESR, Fb, and CRP), BASDAI, ASDAS and BASFI and therapy]. Therefore, based on the presence or absence of certain clinical variable

Table 5. Statistically significant differences between AAU AS and wAAU AS patient groups. AS patients were divided based on their history of AAU and using Mann-Whitney $U$ test the differences between clinical variables of AS patient groups were identified.

\begin{tabular}{lcc}
\hline Group & BASDAI & BASFI \\
\hline AAU AS & $4.33(1.5-9.60)$ & $4.75(0.4-8.00)$ \\
\hline wAAU AS & $2.15(0-6.60)$ & $2.1(0-4.50)$ \\
\hline $\begin{array}{l}\text { AAU AS } \boldsymbol{v s .} \\
\text { wAAU AS }(p)\end{array}$ & $\mathbf{0 . 0 0 2}$ & $\mathbf{0 . 0 0 2}$ \\
\hline
\end{tabular}


or therapy type, each patient received arbitrary scores (see Tables 1). Thus, in AS population the serum sCD147 level indirectly correlated with the history of AAU $(\mathrm{r}=-0.625, p=0.001)$ while 1MMP-2/sCD147 ratio directly correlated with the existence of AAU in the history of AS patients $(\mathrm{r}=0.502, p=0.005)$. For AS patients group, other two additional nearly-significant direct correlations were identified: serum MMP-3 level directly correlated with $\mathrm{Fb}$ level $(\mathrm{r}=0.486$, $p=0.006)$ and serum TIMP-1 level directly correlated with CRP level $(\mathrm{r}=0.493, p=0.006)$. When the AS patients group was divided based on a history of AAU, significant correlations were revealed. Thus, in the AAU AS patients group TIMP-1 level directly correlated with CRP level ( $\mathrm{r}=0.670, p=0.009)$ and tMMP-9/ $\mathrm{sCD} 147$ ratio directly correlated with $\mathrm{Fb}$ level (r $=0.649, p=0.012)$. In the wAAU AS patients group serum MMP-3 level or MMP-3/sCD147 and MMP-3/TIMP-1 ratios directly correlated with $\mathrm{Fb}$ level $(\mathrm{r}=0.652, p=0.006 ; \mathrm{r}=0.662, p$ $=0.005$ and $\mathrm{r}=0.632, p=0.009$, respectively).

In AS patients, the classical inflammation biomarkers (ESR, CRP, Fb) correlated with each other (data not shown). A nearly significant di- rect correlation between CRP and ASDAS values $(r=0.478, p=0.007)$ was found. When AS patients were divided in two subgroups according to CRP values, the subgroup of AS with abnormal CRP values ( $>2 \mathrm{mg} / \mathrm{l})$ presented the highest median values of ASDAS [2.10 (0.202.50) vs. 1.40 (0.70-1.80)]. Besides ASDAS any other characteristic of AS patients, including the presence of AAU, did not correlate with any of the inflammation markers. The same analysis was performed for AS patients with or without a history of AAU. This showed that both ESR and $\mathrm{Fb}$ values directly correlated with BASDAI values in wAAU AS patients $(\mathrm{r}=0.531, p=0.042$; $\mathrm{r}=0.497, p=0.050$, respectively), while CRP values directly correlated with ASDAS values $(\mathrm{r}=0.742, p=0.001)$ in these subgroups of AS patients. In AAU AS patients an indirect correlation between $\mathrm{Fb}$ level and disease duration was identified $(\mathrm{r}=-0.570, p=0.034)$.

Regarding possible associations with the therapy, three nearly significant direct correlations between SSZ therapy and MMP-3, MMP3/TIMP-1 or MMP-3/sCD147 values were found $(\mathrm{r}=0.404, p=0.027 ; \mathrm{r}=0.420, p=0.021$ and $\mathrm{r}=$ $0.396, p=0.030$, respectively). Thus, AS patients

Table 6. Correlation between features of AS patients and type of therapy. Using Speraman's rank correlation the correlations between clinical and paraclinical biomarkers of AS patients and type of therapy were established.

\begin{tabular}{|c|c|c|c|c|c|c|}
\hline Therapy type & $\begin{array}{c}\text { Spearman's rank } \\
\text { correlation }\end{array}$ & $\begin{array}{c}\text { ESR } \\
(\mathrm{mm} / \mathrm{h})\end{array}$ & $\begin{array}{c}\text { CRP } \\
(\mathrm{mg} / \mathrm{l})\end{array}$ & BASDAI & BASFI & ASDAS \\
\hline \multirow{2}{*}{ SSZ } & $\mathrm{r}$ & & & 0.408 & 0.364 & 0.512 \\
\hline & $p$ & & & 0.025 & 0.048 & 0.004 \\
\hline \multirow{2}{*}{ NSAID + SSZ } & $\mathrm{r}$ & & 0.376 & & & 0.482 \\
\hline & $p$ & & 0.041 & & & 0.007 \\
\hline \multirow{2}{*}{ INF } & $\mathrm{r}$ & 0.483 & & & & \\
\hline & $p$ & 0.007 & & & & \\
\hline \multirow{2}{*}{ ADA } & $\mathrm{r}$ & -0.383 & & & & \\
\hline & $p$ & 0.037 & & & & \\
\hline \multirow{2}{*}{$\begin{array}{l}\text { non biologic }+ \\
\text { biologic therapy }\end{array}$} & $\mathrm{r}$ & 0.378 & 0.413 & & & \\
\hline & $p$ & 0.040 & 0.023 & & & \\
\hline
\end{tabular}


with SSZ therapy compared to those without SSZ therapy presented the highest median values of MMP-3 [25.45 ng/ml (11.17-126.87 ng/ $\mathrm{ml})$ vs. $18.26 \mathrm{ng} / \mathrm{ml}(3.13-71.86 \mathrm{ng} / \mathrm{ml})])$, MMP3/TIMP-1 [0.12 (0.06-0.43) vs. 0.08 (0.01-0.26)] and of MMP-3/sCD147 [2.37 (0.34-10.95) vs. $1.15(0.15-3.73)](p=0.031, p=0.023$ and $p$ $=0.034$, respectively, by Mann-Whitney U test). Furthermore, other direct correlations between SSZ therapy and AS severity (evaluated by BAS-
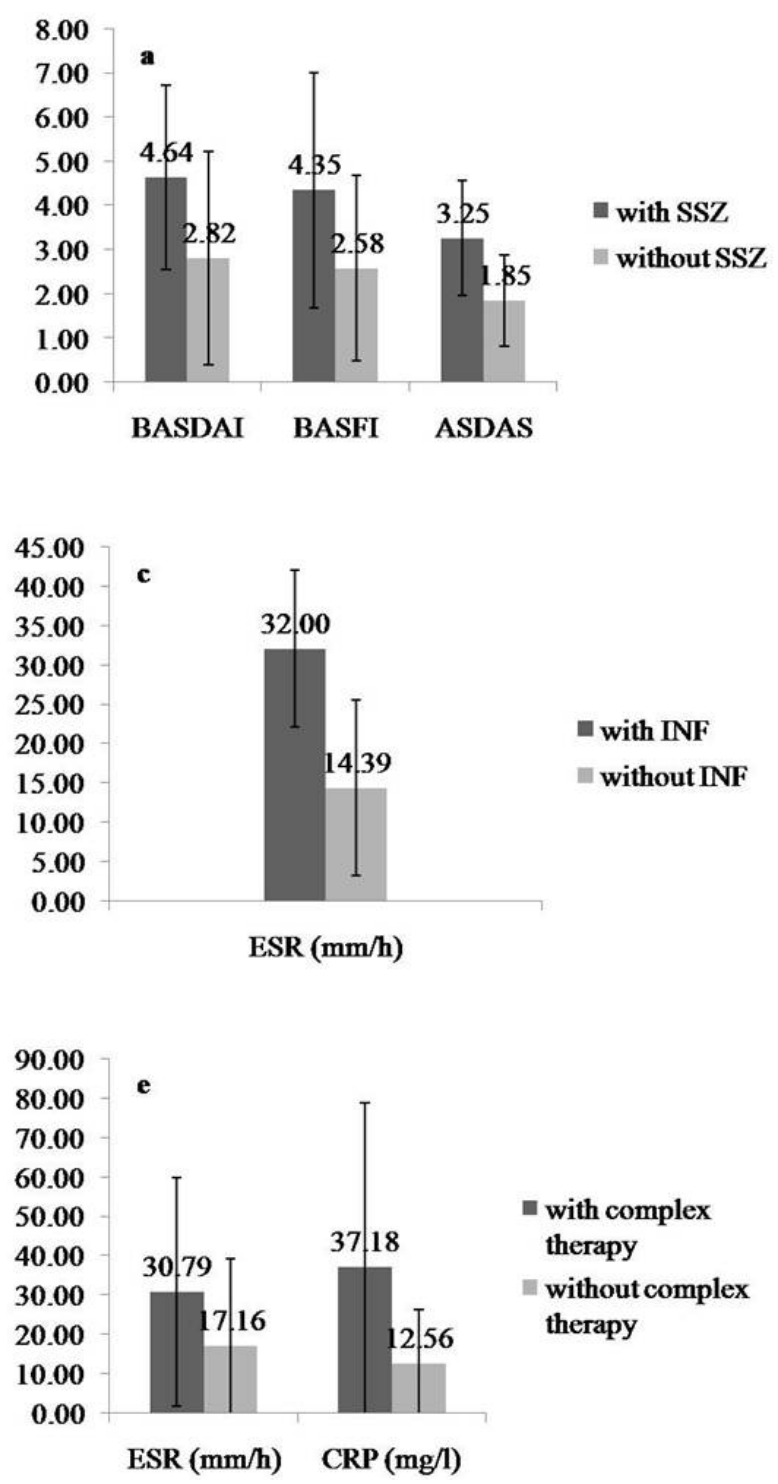

DAI, BASFI and ASDAS) were found (Table 6). Thus, AS patients with SSZ therapy compared to those without SSZ therapy presented the most increased values for BASDAI, BASFI and ASDAS (Figure $3 a)(p=0.029, p=0.051$ and $p=$ 0.006 , respectively, by Mann-Whitney U test). A combination of NSAID and SSZ was associated with high values of CRP and ASDAS (Figure $3 b$ and Table 6 ). INF therapy was directly correlated with ESR values (Figure $3 c$ and Table 6) while
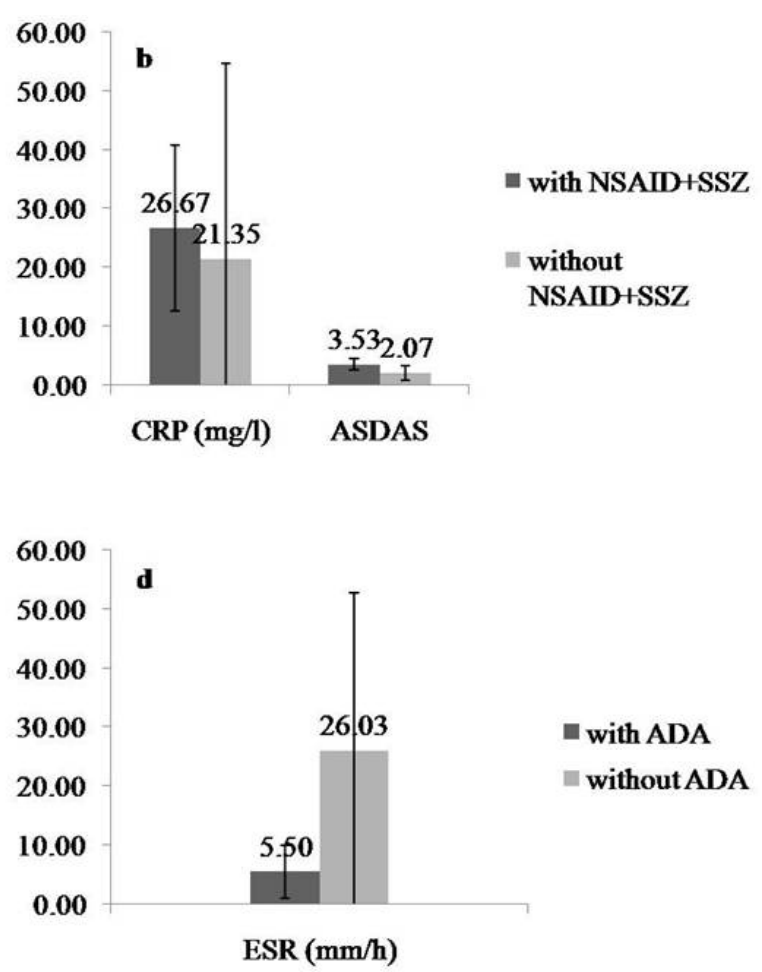

Figure 3. Relationship between clinical or paraclinical features of AS patients and therapy. AS patients were subgrouped depending on non biologic (NSAID or/and SSZ) or biologic (anti-TNF) therapy received by patients during the experimental investigation. The figure presents mean values $\pm \mathrm{SD}$ of some of clinical and paraclinical biomarkers that statistically made the difference between treated (with therapy) and untreated (without therapy) AS patients. 
ADA therapy was associated with low levels of ESR (Figure $3 d$ and Table 6). Other two nearly significant direct correlations between complex (non-biologic plus biologic) therapy and ESR and CRP values in AS patients were identified (Figure $3 e$ and Table 6).

The same analysis was performed for AAU AS and wAAU AS patients. The statistically significant results are presented in Tables 7. As displayed in Table 7A, NSAID therapy was associated with high values of CRP in AAU AS patients. In contrast, SSZ or the combination of SSZ and NSAID therapy in wAAU AS patients directly correlated with BASFI, ASDAS and CRP and indirectly correlated with disease duration (Table 7A). In AAU AS patients, statistically significant correlations were found between SSZ therapy and MMP-3 levels or MMP-3/TIMP-1 ratio values $(\mathrm{r}=0.585, p=0.028 ; \mathrm{r}=0.585, p$ $=0.027$, respectively) as well as between INF or complex therapy (non-biologic plus biologic therapy) and ESR values, or between complex therapy and CRP values (Table 7B). In wAAU AS patients, ADA therapy appeared to have a special feature because it inversely correlated with all classical inflammation markers (Table $7 B)$. An inverse correlation between biologic therapy scores and MMP-3/TIMP-1 ratio values was also identified in AAU AS patients $(\mathrm{r}=$ -0.592, $p=0.026$ ).

\section{Discussion}

The investigation of MMPs / inducer / inhibitor axis in AS patients was conducted in order to identify biomarkers involved in the evolution of AS patients with a history of AAU. This idea was generated by the observation that AAU AS patients seem to have a more rapid evolution of the disease (9). The results of Chen et al., on 146 Chinese AS patients in Taiwan, suggested that the presence of AAU in AS patients is associated with higher disease activity (BASDAI), poor functional ability and advanced physical impairment (BASFI) (38). Recently, another group of investigators showed on 159 patients with AS a relationship between the history of uveitis and AS disease activity (BASDAI) (not statistically significant) and functional impairment (BASFI) (statistically significant) (39). We also tried to obtain a broader picture of the mechanisms that regulate the activity / production of MMPs at systemic level, by SCD147 and TIMP, in AS patients.

In accordance with previously published data, our results showed an increased activity/ level of some MMPs in the sera of AS patients comparing to HDs sera. Thus, the activity of both MMP-2 and MMP-9 was higher in AS patients than in HDs, even if the differences were not statistically significant for our population of AS patients. Moreover, this augmentation was independent of AAU occurrence in the history of AS patients. Earlier reports showed significantly increased releasing of MMP-2 and/or MMP-9 in the serum/plasma of AS patients $(30,31)$. These discrepancies may arise from what and how was analyzed, or from the therapy impact on the level/activity of MMPs; in our study most of the patients received anti-TNF therapy during the evaluation period, drugs previously reported to associate with MMPs reduction (40). However, the serum level of MMP-3, in accordance with previous observations (41), seems to be a good biomarker for differentiating AS patients from HDs, but an episode of AAU in the history of AS patients does not seem to have a decisive role in maintaining over time an augmented level of MMP-3.

Multiple evidences demonstrated the roles of CD147 and/or sCD147 in regulation of MMPs expression/secretion both in normal and pathological processes $(18,26-28,42,43)$. Therefore, in a next step, we examined the level of sCD147 in AS patient and HDs sera. Our results demonstrated that the levels of sCD147 were 
Table 7. Correlation between features of AAU and wAAU AS patients and type of therapy. Using Speraman's rank correlation the correlations between clinical and paraclinical biomarkers of AAU and wAAU AS patients and type of therapy were established.

A.

\begin{tabular}{|c|c|c|c|c|c|c|}
\hline Therapy type & Group & $\begin{array}{l}\text { Spearman's rank } \\
\text { correlation }\end{array}$ & $\begin{array}{c}\text { Disease } \\
\text { duration } \\
\text { (years) }\end{array}$ & BASFI & ASDAS & $\begin{array}{c}\text { CRP } \\
(\mathrm{mg} / \mathrm{l})\end{array}$ \\
\hline \multirow{4}{*}{ NSAID } & \multirow{2}{*}{ AAU } & $\mathrm{r}$ & & & & 0.537 \\
\hline & & $p$ & & & & 0.048 \\
\hline & \multirow{2}{*}{ wAAU } & $\mathrm{r}$ & & & & \\
\hline & & $p$ & & & & \\
\hline \multirow{4}{*}{ SSZ } & \multirow{2}{*}{ AAU } & $\mathrm{r}$ & & & & \\
\hline & & $p$ & & & & \\
\hline & \multirow{2}{*}{ wAAU } & $\mathrm{r}$ & -0.519 & 0.501 & 0.659 & 0.532 \\
\hline & & $p$ & 0.039 & 0.048 & 0.006 & 0.034 \\
\hline \multirow{4}{*}{ NSAID + SSZ } & \multirow{2}{*}{ AAU } & $\mathrm{r}$ & & & & \\
\hline & & $p$ & & & & \\
\hline & \multirow{2}{*}{ wAAU } & $\mathrm{r}$ & -0.519 & 0.501 & 0.659 & 0.532 \\
\hline & & $p$ & 0.039 & 0.048 & 0.006 & 0.034 \\
\hline
\end{tabular}

B.

\begin{tabular}{|c|c|c|c|c|c|}
\hline Therapy type & Group & $\begin{array}{l}\text { Spearman's rank } \\
\text { correlation }\end{array}$ & $\begin{array}{c}\text { ESR } \\
(\mathrm{mm} / \mathrm{h})\end{array}$ & CRP (mg/l) & $\mathrm{Fb}(\mathrm{mg} / \mathrm{dl})$ \\
\hline \multirow{4}{*}{ INF } & \multirow{2}{*}{$\mathrm{AAU}$} & $\mathrm{r}$ & 0.674 & & \\
\hline & & $p$ & 0.008 & & \\
\hline & \multirow{2}{*}{ wAAU } & $\mathrm{r}$ & & & \\
\hline & & $p$ & & & \\
\hline \multirow{4}{*}{ ADA } & \multirow{2}{*}{ AAU } & $\mathrm{r}$ & & & \\
\hline & & $p$ & & & \\
\hline & \multirow{2}{*}{ wAAU } & $\mathrm{r}$ & -0.517 & -0.501 & -0.564 \\
\hline & & $p$ & 0.040 & 0.048 & 0.023 \\
\hline \multirow{4}{*}{$\begin{array}{c}\text { non biologic }+ \\
\text { biologic therapy }\end{array}$} & \multirow{2}{*}{ AAU } & $\mathrm{r}$ & 0.538 & 0.645 & \\
\hline & & $p$ & 0.047 & 0.013 & \\
\hline & \multirow{2}{*}{ wAAU } & $\mathrm{r}$ & & & \\
\hline & & $p$ & & & \\
\hline
\end{tabular}

abnormally elevated in the sera of wAAU AS patients. Unfortunately, there is no information regarding MT1-MMP level or microvesicle containing sCD147 in AS to explain their possible involvement in increasing the level of sCD147 in wAAU AS patients. However, if we consider the significant role of TNF- $\alpha$ in the induction of MT1-MMP at mRNA and protein level (44), this enzyme is expected to be overexpressed in AS and to contribute to sCD147 cleavage and 
releasing. Serum sCD147 may be a valuable biomarker for AS characterization since it differentiates between AAU AS and wAAU AS patients. The sera of AAU AS patients exhibited low $(<$ $9 \mathrm{ng} / \mathrm{ml}, 4$ patients), normal (9 - $14 \mathrm{ng} / \mathrm{ml}, 5$ patients) or high ( $>14 \mathrm{ng} / \mathrm{ml}, 5$ patients) levels of sCD147 while each wAAU AS patient displayed high sCD147 level (> $14 \mathrm{ng} / \mathrm{ml})$. Based on literature data $(20,21)$ we assume that an excessive degradation of the extracellular matrix and tissue destruction may occur when there is a concomitant over-releasing of sCD147 and MMPs. Conversely, when sCD147 is released at normal levels, wound healing may occur. We consider that downregulation of sCD147 in AAU AS patients could also have other pathological consequences. AAU AS patients exhibit a significant imbalance between MMP-2 activity and the level of circulating sCD147, 1MMP-2/sCD147 ratio being more increased in this group of patients than in wAAU AS patient or HDs groups. In contrast, wAAU AS patients exhibit a significant imbalance between circulating levels of MMP-3 and sCD147, their MMP-3/sCD147 ratio being lower than in AAU AS patients and higher than in HDs. These observations suggest impairment of at least one of the mechanisms involved in maintaining sCD147 / MMPs homeostasis in AS.

To maintain homeostasis, not only the relationship between MMPs and their inducers plays an important role but also the balance between MMPs and their natural inhibitors (45). Our results demonstrated increased levels of TIMP-1 in AS patients compared to HDs. An earlier paper reported unchanged TIMP-1 levels in the aqueous humor of patients with uveitis (12), suggesting that an episode of uveitis in AS patients history might not influence TIMP-1 level, as our results showed. The balance between MMPs and its natural inhibitor TIMP-1 seems to be dysfunctional in AS patients irrespective of their AAU history. This suggests that, even if TIMP1 level is increased in the sera of AS patients it is not enough to compensate for the exacerbated production of MMPs.

The correlations between experimental biomarkers and clinical variables, identified in our study, suggested that if in wAAU AS patients $\mathrm{Fb}$ exacerbated production contributes to augmentation of MMP-3 release, in AAU AS patients high levels of CRP induce increased release of TIMP-1 at systemic level. The correlation with $\mathrm{Fb}$ level was not unexpected since other groups of researchers have already demonstrated $\mathrm{Fb}$ role in cell activation and subsequently in MMPs production (46) Furthermore, Tarhini et al. (47) demonstrated a relationship between TIMP-1 and CRP; these biomarkers by their multiple activities have significant prognostic capacity in patients with melanoma. These results underline the potential role of inflammation mediators $(\mathrm{Fb}$ and CRP) in the dysregulation of the balance between MMPs inducer, MMPs and MMPs inhibitors which contribute to chronic inflammation and tissue damage in AS patients. As noted, if cellular CD147 expression seems to be associated with the inflammation markers (ESR and CRP) (28), at systemic level, Fb appears to be associated with impaired balance between MMP-3 and sCD147. The correlations between clinical variables, revealed especially the relationship between CRP and ASDAS since this disease activity score is established taking into account CRP value (35). Only for wAAU AS patients the role of ESR or $\mathrm{Fb}$ on disease gravity was emphasized by direct correlations with BASDAI, while for AAU AS patients $\mathrm{Fb}$ levels seemed to be in an indirect relationship with disease duration.

Our results provide additional arguments to the existing data or approach directions that until now have not been explored in extra-articular complications of AS, such as AAU. Consistent with the results of other groups of investigators $(9,38,39,48)$, our data emphasize the existence of elevated values of BASDAI and BASFI in AAU AS patients suggesting that these patients develop a more aggressive disease than wAAU 
AS patients. For the first time, we identified MMP-2/sCD147 ratio as a new variable to better characterize AAU AS patients. Altogether, our data suggest that the identification of abnormalities in SCD147 / MMPs / TIMPs axis together with BASDAI and BASFI evaluation might be useful tools for clinicians to predict and to monitor the disease evolution in AS patients, especially in those with a AAU history. On the other hand, positive or negative correlations between some clinical (BASFI, ASDAS, ESR and CRP) and experimental (MMP-3, MMP-3/TIMP-1 and MMP-3/sCD147) variables in AS patients receiving anti-inflammatory or biologic therapy suggest the requirement of a more complex biological evaluation of AS patients in order to monitor the effectiveness of therapy.

\section{Declaration of interest}

The authors report no conflicts of interest and alone are responsible for the content and writing of the paper.

\section{Acknowledgements}

We thank Ms. Doina Proteasa, from Cantacuzino National Institute for Research and Development in Microbiology and Immunology (NIRDMI), Bucharest, Romania for technical support. This study was partial founded by the Grant No. PN 09 22/2012 of Cantacuzino NIRDMI and internal supported also.

\section{Abbreviations}

AS - Ankylosing Spondylitis

NOS-2 - Nitric Oxide Synthase-2

MMPs - Matrix Metalloproteinases

EMMPRIN/CD147 - Extracellular Matrix

Metalloproteinases Inducer/CD147

TIMPs - Tissue Inhibitors of Matrix Metalloproteinases

AAU - Acute Anterior Uveitis
HDs - Healthy Donors

ELISA - Enzyme-Linked Immunosorbent Assay sCD147 - soluble CD147

HLA-B27 - Human Leukocytes Antigen-B27

MHC - Major Histocompatibility Complex

IL-23R - Interleukine-23 receptor

ERAP1 - endoplasmic reticulum aminopeptidase 1

ANTXR2 - Anthrax toxin receptor 2

CARD9 - Caspase recruitment domain-containing protein 9

IL-1R - Interleukin-1 receptor

TLR-4 - Toll-Like Receptor-4

BASDAI - Bath Ankylosing Spondylitis Disease Activity Index

BASFI - Bath Ankylosing Spondylitis Functional Index

TNF- $\alpha$ - Tumor Necrosis Factor- $\alpha$

IFN- $\gamma$ - Interferon- $\gamma$

IL- $1 \alpha$ - Interleukine- $1 \alpha$

MCT1, 3 and 4 - Monocarboxylate Transporter

1,3 and 4

EGF - Epidermal Growth Factor

TGF- $\beta$ - Transforming Growth Factor- $\beta$

MEK - Mitogen-activated protein kinase

MT1-MMP - Membrane-type1-Matrix Metalloproteinase

CRP - C-Reactive Protein

ESR - Erythrocyte Sedimentation Rate

AAU AS - AS patients with a history of AAU

wAAU AS - AS patients without a history of AAU

MRI - Magnetic Resonance Imaging

$\mathrm{Fb}$ - Fibrinogen

ASDAS - Ankylosing Spondylitis Disease Activity Score

NSAIDs - nonsteroidal anti-inflammatory drugs

SSZ - Sulphasalazine

INF - Infliximab

ADA - Adalimumab

ETA - Etanercept

GOL - Golimumab

SDS-PAGE - Sodium Dodecyl Sulfate-Poly- 
acrylamide Gel Electrophoresis

IMMP - latent MMP form

aMMP - active MMP form

tMMP - total MMP

mRNA - messenger Ribonucleic Acid

\section{References}

1. Slobodin G, Rosner I, Rimar D, Boulman N, Rozenbaum M, Odeh M. Ankylosing spondylitis: field in progress. Isr Med Assoc J. 2012;14(12):763-7.

2. Thomas GP, Brown MA. Genetics and genomics of ankylosing spondylitis. Immunol Rev. 2010;233(1):16280. DOI: 10.1111/j.0105-2896.2009.00852.x

3. Snelgrove T, Lim S, Greenwood C, Peddle L, Hamilton S, Inman R, et al. Association of toll-like receptor 4 variants and ankylosing spondylitis: a case-control study. J Rheumatol. 2007;34(2):368-70.

4. De Vlam K. Soluble and tissue biomarkers in ankylosing spondylitis. Best Pract Res Clin Rheumatol. 2010;24(5):671-82. DOI: 10.1016/j.berh.2010.05.009

5. Wang QH, Zhang SZ, Xue J, Wu HX. Serum metalloproteinase-3 levels in assessing efficacy of Etanercept in patients with ankylosing spondylitis. Zhejiang Da Xue Xue Bao Yi Xue Ban. 2010;39(4):409-14 (abstract).

6. Maksymowych WP, Landewé R, Conner-Spady B, Dougados M, Mielants H, van der Tempel H, Poole AR, Wang N, van der Heijde D. Serum matrix metalloproteinase 3 is an independent predictor of structural damage progression in patients with ankylosing spondylitis. Arthritis Rheum. 2007;56(6):1846-53 DOI: 10.1002/ art.22589

7. Gouveia EB, Elmann D, Morales MS. Ankylosing spondylitis and uveitis: overview. Rev Bras Reumatol. 2012;52(5):742-56.

8. El Maghraoui A. Extra-articular manifestations of ankylosing spondylitis: prevalence, characteristics and therapeutic implications. Eur J Intern Med. 2011;22(6):554-60. DOI: 10.1016/j.ejim.2011.06.006

9. Robertson LP, Davis MJ. A longitudinal study of disease activity and functional status in a hospital cohort of patients with ankylosing spondylitis. Rheumatology (Oxford). 2004;43(12):1565-8. DOI: 10.1093/rheumatology/keh386

10. Chang JH, McCluskey PJ, Wakefield D. 2009. Acute Anterior Uveitis and HLA-B27: What's New? in Uveitis and Immunological Disorders Progress III, U Pleyer, JV Forrester eds. Springer-Verlag, Berlin Heidelberg. p. 9-18. DOI: 10.1007/978-3-540-69459-5_2

11. Li H, Yoneda M, Takeyama M, Sugita I, Tsunekawa H, Yamada H, et al. Effect of infliximab on tumor necrosis factor-alpha-induced alterations in retinal microvascular endothelial cells and retinal pigment epithelial cells. J Ocul Pharmacol Ther. 2010;26(6):549-56. DOI: 10.1089/jop.2010.0079

12. Di Girolamo N, Verma MJ, McCluskey PJ, Lloyd A, Wakefield D. Increased matrix metalloproteinases in the aqueous humor of patients and experimental animals with uveitis. Curr Eye Res. 1996;15(10):1060-8. DOI: $10.3109 / 02713689609017656$

13. Cuello C, Wakefield D, Di Girolamo N. Neutrophil accumulation correlates with type IV collagenase/gelatinase activity in endotoxin induced uveitis. Br J Ophtalmol. 2002;86(3):290-5. DOI: 10.1136/bjo.86.3.290

14. Yamada H, Yoneda M, Inaguma S, Watanabe D, Banno $\mathrm{S}$, Yoshikawa $\mathrm{K}$, et al. Infliximab counteracts tumor necrosis factor- $\alpha$-enhanced induction of matrix metalloproteinases that degrade claudin and occludin in non-pigmented ciliary epithelium. Biochem Pharmacol. 2013;85(12):1770-82. DOI: 10.1016/j.bcp.2013.04.006

15. Martin TM, Bye L, Modi N, Stanford MR, Vaughan R, Smith JR, et al. Genotype analysis of polymorphisms in autoimmune susceptibility genes, CTLA-4 and PTPN22, in an acute anterior uveitis cohort. Mol Vis. 2009; $15: 208-12$.

16. Fossum S, Mallett S, Barclay AN. The MRC OX-47 antigen is a member of the immunoglobulin superfamily with an unusual transmembrane sequence. Eur J Immunol. 1991;21(3):671-9. DOI: 10.1002/eji.1830210320

17. Koch C, Staffler G, Hüttinger R, Hilgert I, Prager E, Cerný J, et al. T cell activation-associated epitopes of CD147 in regulation of the $\mathrm{T}$ cell response, and their definition by antibody affinity and antigen density. Int Immunol. 1999;11(5):777-86. DOI: 10.1093/intimm/11.5.777

18. Määttä M, Tervahartiala $\mathrm{T}$, Kaarniranta $\mathrm{K}$, Tang Y, Yan L, Tuukkanen J, et al. Immunolocalization of EMMPRIN (CD147) in the human eye and detection of soluble form of EMMPRIN in ocular fluids. Curr Eye Res. 2006;31(11):917-24. DOI: $10.1080 / 02713680600932290$

19. Biswas C. Tumor cell stimulation of collagenase production by fibroblasts. Biochem Biophys Res Commun. 1982;109(3):1026-34. DOI: 10.1016/0006291X(82)92042-3

20. Philp NJ, Ochrietor JD, Rudoy C, Muramatsu T, Linser PJ. Loss of MCT1, MCT3, and MCT4 expression in the retinal pigment epithelium and neural retina of the 5A11/basigin-null mouse. Invest Ophthalmol Vis Sci. 2003;44(3):1305-11. DOI: 10.1167/iovs.02-0552

21. Gabison EE, Mourah S, Steinfels E, Yan L, Hoang-Xuan T, Watsky MA, et al. Differential expression of extracellular matrix metalloproteinase inducer (CD147) in normal and ulcerated corneas: role in epithelio-stromal interactions and matrix metalloproteinase induction. Am J Pathol. 2005;166(1):209-19. DOI: 10.1016/ S0002-9440(10)62245-6

22. Iacono KT, Brown AL, Greene MI, Saouaf SJ. CD147 
immunoglobulin superfamily receptor function and role in pathology. Exp Mol Pathol. 2007;83(3):283-95. DOI: 10.1016/j.yexmp.2007.08.014

23. Taylor PM, Woodfield RJ, Hodgkin MN, Pettitt TR, Martin A, Kerr DJ, et al. Breast cancer cell-derived EMMPRIN stimulates fibroblast MMP2 release through a phospholipase $\mathrm{A}(2)$ and 5-lipoxygenase catalyzed pathway. Oncogene. 2002;21(37):5765-72. DOI: 10.1038/ sj.onc. 1205702

24. Sidhu SS, Mengistab AT, Tauscher AN, LaVail J, Basbaum C. The microvesicle as a vehicle for EMMPRIN in tumor-stromal interactions. Oncogene. 2004;23(4):956-63. DOI: 10.1038/sj.onc. 1207070

25. Egawa N, Koshikawa N, Tomari T, Nabeshima K, Isobe T, Seiki M. Membrane type 1 matrix metalloproteinase (MT1-MMP/MMP-14) cleaves and releases a $22-\mathrm{kDa}$ extracellular matrix metalloproteinase inducer (EMMPRIN) fragment from tumor cells. J Biol Chem. 2006;281(49):37576-85. DOI: 10.1074/jbc. M606993200

26. Onodera J, Onodera S, Kondo E, Betsuyaku T, Yasuda K. A soluble factor (EMMPRIN) in exudate influences knee motion after total arthroplasty. Knee Surg Sports Traumatol Arthrosc. 2009;17(3):298-304. DOI: 10.1007/s00167-008-0688-6

27. Yanaba K, Asano Y, Tada Y, Sugaya M, Kadono T, Hamaguchi Y, et al. Increased serum soluble CD147 levels in patients with systemic sclerosis: association with scleroderma renal crisis. Clin Rheumatol. 2012;31(5):835-9. DOI: 10.1007/s10067-012-1949-9

28. Wang M, Huang ZX, Pan YF, Zhang FC, Zheng BR, Deng WM, et al. Expressions of CD147 in peripheral monocytes and $\mathrm{T}$ lymphocytes of patients with ankylosing spondylitis. Zhonghua Yi Xue Za Zhi. 2010;90(41):2902-6 (abstract).

29. Dhir V, Srivastava R, Aggarwal A. Circulating Levels of Soluble Receptor Activator of NF- $\kappa$ B Ligand and Matrix Metalloproteinase 3 (and Their Antagonists) in Asian Indian Patients with Ankylosing Spondylitis. Int J Rheumatol. 2013;2013:814350. DOI: $10.1155 / 2013 / 814350$

30. Veidal SS, Larsen DV, Chen X, Sun S, Zheng Q, Bay-Jensen AC, et al. MMP mediated type V collagen degradation $(\mathrm{C} 5 \mathrm{M})$ is elevated in ankylosing spondylitis. Clin Biochem. 2012;45(7-8):541-6 DOI: 10.1016/j. clinbiochem.2012.02.007

31. Mattey DL, Packham JC, Nixon NB, Coates L, Creamer P, Hailwood S, et al. Association of cytokine and matrix metalloproteinase profiles with disease activity and function in ankylosing spondylitis. Arthritis Res Ther. 2012;14(3):R127 DOI: 10.1186/ar3857

32. Moll JM, Wright V. New York clinical criteria for ankylosing spondylitis. A statistical evaluation. Ann Rheum Dis. 1973;32(4):354-63. DOI: 10.1136/ard.32.4.354

33. Van der Linden S, Valkenburg HA, Cats A. Evalua- tion of diagnostic criteria for ankylosing spondylitis. A proposal for modification of the New York criteria. Arthritis Rheum. 1984;27(4):361-8. DOI: 10.1002/ art.1780270401

34. Garrett S, Jenkinson T, Kennedy LG, Whitelock H, Gaisford P, Calin A. A new approach to defining disease status in ankylosing spondylitis: the Bath Ankylosing Spondylitis Disease Activity Index. J Rheumatol. 1994;21(12):2286-91.

35. Lukas C, Landewé R, Sieper J, Dougados M, Davis J, Braun J, et al. Assessment of SpondyloArthritis international Society. Development of an ASAS-endorsed disease activity score (ASDAS) in patients with ankylosing spondylitis. Ann Rheum Dis. 2009;68(1):18-24. DOI: 10.1136/ard.2008.094870

36. Calin A, Garrett S, Whitelock H, Kennedy LG, O'Hea $\mathrm{J}$, Mallorie P, et al. A new approach to defining functional ability in ankylosing spondylitis: the development of the Bath Ankylosing Spondylitis Functional Index. J Rheumatol. 1994;21(12):2281-5.

37. Matache C, Stefanescu M, Dragomir C, Tanaseanu S, Onu A, Ofiteru A, et al. Matrix metalloproteinase-9 and its natural inhibitor TIMP-1 expressed or secreted by peripheral blood mononuclear cells from patients with systemic lupus erythematosus. J Autoimmun. 2003; 20(4): 323-31. DOI: 10.1016/S0896-8411(03)00037-4

38. Chen CH, Lin KC, Chen HA, Liao HT, Liang TH, Wang $\mathrm{HP}$, et al. Association of acute anterior uveitis with disease activity, functional ability and physical mobility in patients with ankylosing spondylitis: a cross-sectional study of Chinese patients in Taiwan. Clin Rheumatol. 2007;26(6):953-7. DOI: 10.1007/s10067-006-0403-2

39. Berg IJ, Semb AG, van der Heijde D, Kvien TK, Hisdal $\mathrm{J}$, Olsen IC, et al. Uveitis is associated to hypertension and atherosclerosis in patients with ankylosing spondylitis: a cross-sectional study. Semin Arthritis Rheum. 2014. pii: S0049-0172(14)00111-5. doi: 10.1016/j. semarthrit.2014.05.017. DOI: 10.1016/j.semarthrit.2014.05.017

40. Cordiali-Fei P, Trento E, D'Agosto G, Bordignon V, Mussi A, Ardigó M, et al. Effective therapy with anti-TNF-alpha in patients with psoriatic arthritis is associated with decreased levels of metalloproteinases and angiogenic cytokines in the sera and skin lesions. Ann N Y Acad Sci. 2007;1110:578-89. DOI: 10.1196/ annals.1423.062

41. Chen CH, Lin KC, Yu DT, Yang C, Huang F, Chen HA, et al. Serum matrix metalloproteinases and tissue inhibitors of metalloproteinases in ankylosing spondylitis: MMP-3 is a reproducibly sensitive and specific biomarker of disease activity. Rheumatology (Oxford). 2006;45(4):41420. DOI: $10.1093 /$ rheumatology/kei208

42. Yurchenko V, Constant S, Eisenmesser E, Bukrinsky M. Cyclophilin-CD147 interactions: a new target for anti-inflammatory therapeutics. Clin Exp 
Immunol. 2010;160(3):305-17. DOI: 10.1111/j.13652249.2010.04115.x

43. Pistol G, Matache C, Calugaru A, Stavaru C, Tanaseanu $\mathrm{S}$, Ionescu R, et al. Roles of CD147 on T lymphocytes activation and MMP-9 secretion in systemic lupus erythematosus. J Cell Mol Med. 2007;11(2):339-48. DOI: 10.1111/j.1582-4934.2007.00022.x

44. Han YP, Tuan TL, Wu H, Hughes M, Garner WL. TNF-alpha stimulates activation of pro-MMP2 in human skin through NF-(kappa)B mediated induction of MT1-MMP. J Cell Sci. 2001;114(Pt 1):131-139.

45. Bellayr IH, Mu X, Li Y. Biochemical insights into the role of matrix metalloproteinases in regeneration: challenges and recent developments. Future Med Chem. 2009;1(6):1095-111. DOI: 10.4155/fmc.09.83
46. Kaneider NC, Mosheimer B, Günther A, Feistritzer C, Wiedermann CJ. Enhancement of fibrinogen-triggered pro-coagulant activation of monocytes in vitro by matrix metalloproteinase-9. Thromb J. 2010;8(1):2-7. DOI: $10.1186 / 1477-9560-8-2$

47. Tarhini AA, Lin Y, Yeku O, LaFramboise WA, Ashraf M, Sander C, et al. A four-marker signature of TNFRII, TGF- $\alpha$, TIMP-1 and CRP is prognostic of worse survival in high-risk surgically resected melanoma. J Transl Med. 2014,12:19. DOI: 10.1186/1479-5876-1219

48. Gehlen M, Regis KC, Skare TL. Demographic, clinical, laboratory and treatment characteristics of spondyloarthritis patients with and without acute anterior uveitis. Sao Paolo Med J. 2012;130(3):141-4. DOI: 10.1590/ S1516-31802012000300002 